More praise for In the Shadow of the Epidemic:

"In the second decade of AIDS, the short-term emergency solutions of the 8 os are no longer enough; we need a way of living and staying uninfected for an indefinite future, about which many gay men are at best ambivalent. No one has risen to this new challenge more articulately than Walt Odets. In the Shadow of the Epidemic, already controversial, is essential reading for anyone who cares about AIDS prevention or about gay men. It is a moving, courageous, and profoundly humane book. And I believe it no exaggeration to say that it will save many lives."-Michael Warner, editor of Fear of a Queer Planet

"Dr. Odets's work is extraordinarily insightful, provocative, and courageous."-Benjamin Schatz, Executive Director, Gay and Lesbian Medical Association

"This will be the literature on the subject. In the Shadow of the Epidemic is a remarkable work. Odets's practice, his clarity of thought and introspection have provided us with a true gift."-Alvin Novick, Yale University and editor-in-chief of AIDS \& Public Policy Journal 


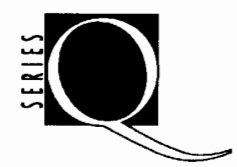

A series edited by Michèle Aina Barale, Jonathan Goldberg,

Michael Moon, and Eve Kosofsky Sedgwick 


\section{In the Shadow}

of the Epidemic

BEING HIV-NEGATIVE IN THE AGE OF AIDS

\section{Walt Odets}


(C) 1995 Duke University Press

All rights reserved

Printed in the United States of America on acid-free paper $\infty$

Typeset in Berkeley Medium by Tseng Information Systems, Inc.

Library of Congress Cataloging-in-Publication Data appear on the last printed page of this book.

Second printing, 1995 
for Robb

What will life do to us, if it did that to him? 
